\title{
Fossil soricids (Soricomorpha: Soricidae) in collection of Geological Institute of the Russian Academy of Sciences (GIN, Russia, Moscow): actual data on 2021
}

\author{
Leonid L. Voyta*, Vladimir S. Zazhigin \& Lyudmila Yu. Kryuchkova
}

\begin{abstract}
This note represents actual information on the composition of currently investigated Neogene and Pleistocene collections of soricid shrews permanently stored in collections of the Geological Institute of the Russian Academy of Sciences (GIN, Russia, Moscow), clarification of the collection catalogue numbers of the keeping specimens and short collectors information. At present, most shrew type specimens (e.g., Shargainosorex angustirostris) and some other specimens $(\mathrm{n}=36)$ from the GIN fossil collection, which were investigated from 2016 to 2021, have 3D digital image stacks (preliminary data sets) that had been obtained using computed microtomography. All of the 3D digital image stacks of the GIN specimens are keeping in the Zoological Institute of the Russian Academy of Sciences (ZIN, Russia, Saint Petersburg) digital repository. The paper represents technical information on each digitized item.
\end{abstract}

How to cite this article: Voyta L.L., Zazhigin V.S., Kryuchkova L.Yu. 2021. Fossil soricids (Soricomorpha: Soricidae) in collection of Geological Institute of the Russian Academy of Sciences (GIN, Russia, Moscow): actual data on 2021 // Russian J. Theriol. Vol.20. No.2. P.136-142. doi: 10.15298/rusjtheriol.20.2.03

KEY WORDS: mammals, Soricidae, palaeotheriological collection, digital repository, collection catalogue numbers, computed microtomography.

Leonid L.Voyta [leonid.voyta@zin.ru], Zoological Institute of the Russian Academy of Sciences, Universitetskaya emb. 1, Saint Petersburg 199034, Russia; Vladimir S. Zazhigin [zazhvol@gmail.com], Geological Institute of the Russian Academy of Sciences, Pyzhevskii per. 7, Moscow 109017, Russia; Lyudmila Yu. Kryuchkova [2106@list.ru], Saint Petersburg State University, Saint Petersburg, Russia.

\section{Ископаемые землеройки (Soricomorpha: Soricidae) в коллекции Геологического института Российской академии наук (Россия, Москва): актуальные данные на 2021 год}

\section{Л.Л. Войта*, В.С. Зажигин, Л.Ю. Крючкова}

РЕЗЮМЕ. Настоящее сообщение представляет актуальную информацию о составе исследуемых в настоящее время коллекций неогеновых и плейстоценовых землероек, постоянно хранящихся в коллекциях Геологического института РАН (ГИН РАН, Россия, Москва), уточнение каталожных номеров хранящихся экземпляров и краткие сведения из первичной информации сборщиков материала. В настоящее время большая часть типовых экземпляров землероек (например, Shargainosorex angustirostris) и некоторых других образцов $(\mathrm{n}=36)$ из палеонтологической коллекции ГИН РАН, исследованные с 2016 по 2021 гг., имеют трехмерные цифровые архивы изображений (первичные наборы данных), полученные с помощью компьютерной микротомографии. Все трехмерные цифровые архивы изображений экземпляров ГИН РАН хранятся в цифровом хранилище Зоологического института РАН (ЗИН РАН, Россия, Санкт-Петербург). В тексте представлена техническая информация по каждому оцифрованному экземпляру.

КЛЮЧЕВЫЕ СЛОВА: млекопитающие, Soricidae, палеотериологическая коллекция, цифровое хранилище, номера коллекционного каталога, компьютерная микротомография.

\footnotetext{
* Corresponding author
} 


\section{Introduction}

The unique fossil collection of Neogene and Pleistocene soricids (Soricimorpha: Soricidae) of the Geological Institute of the Russian Academy of Sciences (GIN, Russia, Moscow) was collected by Vladimir S. Zazhigin from the beginning of the 1960-s to 2010-s during the field trips in Mongolia, Kazakhstan, and Russia (southwest and northeast regions of Siberia). The collection represents dental and bone material of variable preservation. The uniqueness of these materials is that the fossils originated from the broad territories, which still remain a "white spot" in shrew investigations. The GIN collection has already served he basis for new fossil taxa of shrews. These include Nectogalinia altaica (Soricinae: Beremendiini) described by Gureev (1979), Paranourosorex seletiensis (Soricinae: Anourosoricini) described by Storch and Zazhigin (1996) and Shargainosorex angustirostris (Crocidosoricinae) described by Zazhigin and Voyta (2018) and we hope that this list will grow. The GIN collection materials on beremendiin shrews (Soricinae: Beremendiini) allowed us to perform the taxonomic revision of the tribe and refine the taxonomic position of Nectogalinia altaica (Zazhigin \& Voyta, 2019).

During the analyses of the materials on Shargainosorex and Beremendiini and their description, there was some uncertainty with the collection catalogue numbers that had been assigned the fossil specimens. In both articles (Zazhigin \& Voyta, 2018, 2019), we ascribed two numbers for each specimen, namely numbers of the GIN collection and numbers of the Zoological Institute of the Russian Academy of Sciences (ZIN, Russia, Saint Petersburg) collection due to the temporal storage causes. The main purpose of the current note is the clarification of the catalogue numbers and the place of the permanent storage of the materials. In addition, we will provide additional information on specimens.

\section{Specimens storage and scientific curators of the collection}

All specimens of Shargainosorex angustirostris (Zazhigin \& Voyta, 2018; Appendix 1) and most parts of Beremendiini (Zazhigin \& Voyta, 2019; Appendix 2) except several specimens from ZIN collection are permanently stored in the collection of the Geological Institute of the Russian Academy of Sciences (GIN, Russia, Moscow). The valid catalogue's numbers that can support availability to the collection material are GIN's numbers, which have all specimens in mentioned articles. The ZIN numbers are invalid.

The scientific curator of the collections is the Senior Scientist Researcher of GIN Dr. Vladimir S. Zazhigin (zazhvol@gmail.com). The total count of the investigated and published specimens from GIN's collection of shrews are 270 (Shargainosorex, $n=216$; Beremendiini, $n=54$ ).

\section{D digital image stacks of the GIN specimens}

Since 2016, LV and VZ interact with the Resource Centre for X-ray Diffraction Studies of Saint Petersburg State University (RC, Saint Petersburg, Russia) for practicing techniques and developing particular approaches on the computed microtomography $(\mu \mathrm{CT})$ usage for shrews investigation. Together with Scientist Engineer of RC Dr. Lyudmila Yu. Kryuchkova we could develop several new protocols for the sample preparing for $\mu \mathrm{CT}$ and described a new type of the endodontic features of soricids (Voyta et al., 2020). As a result, we obtained 3D digital image stacks (preliminary data sets as TIFF and JPEG-file volumes) of the numerous fossil specimens from the GIN collection. All obtained digital image stacks are stored in the ZIN digital repository that will soon receive a separate web page on the ZIN Collections portal (http://zin.ru/collections/ index en.html). Each stack after reconstruction of the surfaces (3D models obtaining) and publishing will be presented on the collection ZIN Collections portal. The total number of the $\mu \mathrm{CT}$-scanned specimens is 34 (see information in Appendix 1). Currently, several specimens were reconstructed used Avizo 2019.1 (FEI SAS), have 3D models (Fig. 1) and can be used for publication, threedimension reconstructions of the extinct shrews skull and remote access to specimens by non-resident scientists.

The scientific curator of the digital collections of shrews is the Senior Scientist Researcher of ZIN Dr. Leonid L. Voyta (leonid.voyta@zin.ru). All materials will be available upon request after it published as 3D models. For example, all 3D models published by Voyta et al. (2020) are available on request. The technical information and list of the 3D models of the $S$. angustirostris holotype see in 3D data set ZIN-PT3D-01(1-6) by link: http://zin.ru/labs/theriology/eng/ research/index.html

ACKNOWLEDGEMENTS. The mentioned scientific studies, collection analysis and technical developments on $\mu \mathrm{CT}$ usage were completed within the framework of the Federal themes of ZIN no. AAAA-A19-119032590102-7 "Phylogeny, morphology, and systematics of placental mammals" and GIN "Paleontological grounds for the stratigraphic scale of the upper Cenozoic of Northern Eurasia". This study was partly funded by Project no. 19-04-00049 of the Russian Foundation for Basic Research. The 3D digital image stacks were obtained with the use of the equipment of the Resource Centre for X-ray Diffraction Studies of Saint Petersburg State University.

\section{References}

Gureev A.A. 1979. The Fauna of the USSR. Mammals. Vol.4, No.2. Insectivorous: Hedgehogs, Moles, and Shrews (Erinaceidae, Talpidae, Soricidae). Leningrad: Izdatel'stvo Nauka. 503 p. [in Russian]. 
Storch G. \& Zazhigin V.S. 1996. Taxonomy and phylogeny of the Paranourosorex lineage, Neogene of Eurasia (Mammalia: Soricidae: Anourosoricini) // Paläontologische Zeitschrift. Bd.70. S.257-268.

Voyta L.L., Zazhigin V.S., Petrova E.A. \& Krjutchkova L.Yu. 2020. Shrew dentition (Lipotyphla: Soricidae) — endodontic morphology and its phylogenetic resolving power// Mammal Research. Vol.65. P.33-48.
Zazhigin V.S. \& Voyta L.L. 2018. A new middle Miocene crocidosoricine shrew from the Mongolian Shargain Gobi Desert // Acta Palaeontologica Polonica. Vol.63. P.171-187. Zazhigin V.S. \& Voyta L.L. 2019. Northern Asian PliocenePleistocene beremendiin shrews (Mammalia, Lipotyphla, Soricidae): a description of material from Russia (Siberia), Kazakhstan, and Mongolia and the paleobiology of Beremendia // Journal of Paleontology. Vol.93. P.1234-1257.
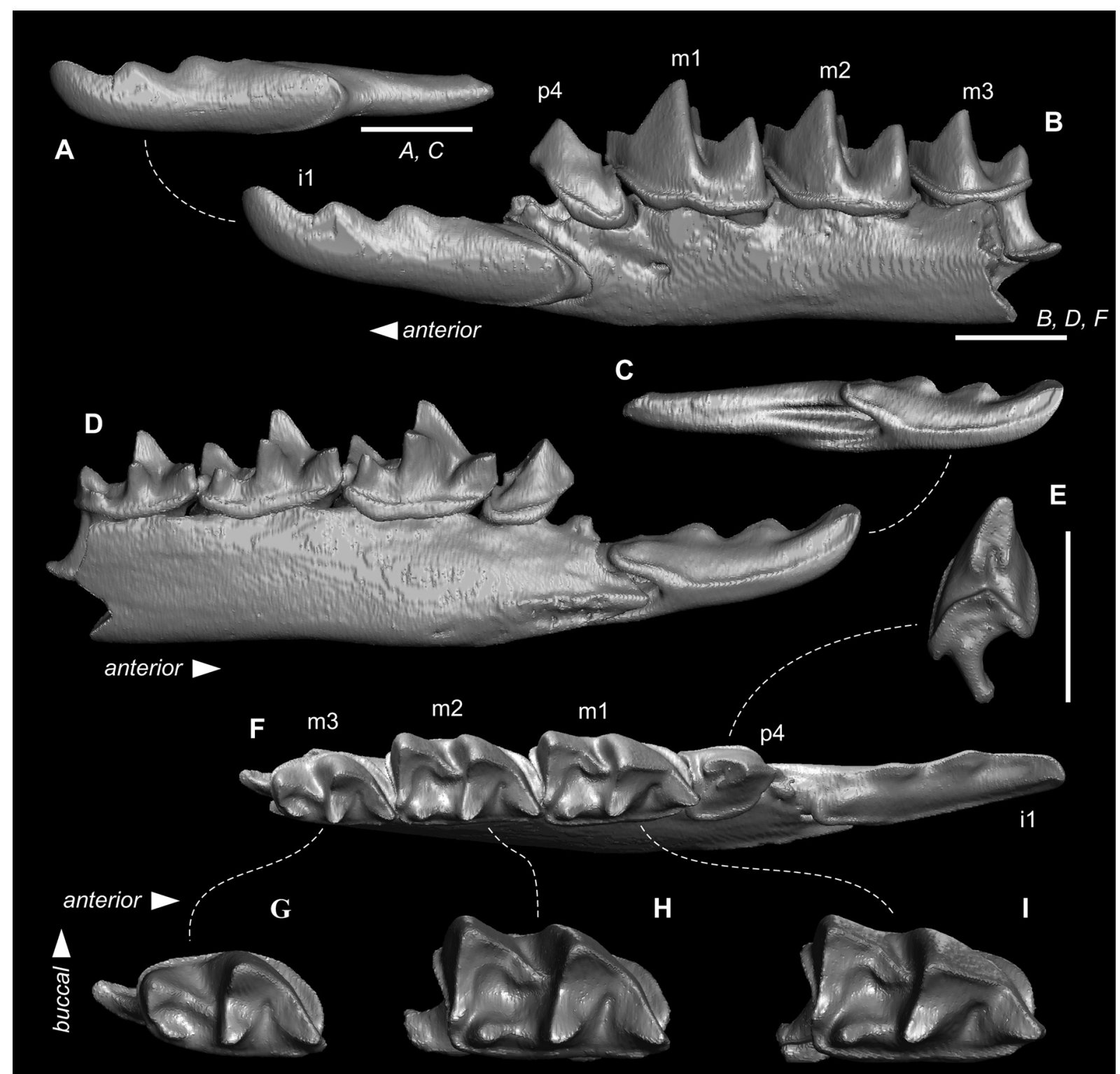

G-I

Fig. 1. Tree-dimension models of the holotype of middle Miocene Shargainosorex angustirostris Zazhigin et Voyta, 2018 (GIN 959/1010) based on $\mu$ CT-scanning: (A) Model of the il of the holotype in lateral view; (B) Actual condition of the holotype a model of the right dentary in lateral view; (C) ibid., in medial view; (D) Actual condition of the holotype - a model of the right dentary in medial view; (E) Model of the $\mathrm{p} 4$ of the holotype in subocclusal view; (F) Actual condition of the holotype - a model of the right dentary in occlusal view; (G) Model of the $\mathrm{m} 1$ of the holotype in occlusal view; (H) ibid., $\mathrm{m} 2$ in occlusal view; (I) ibid., $\mathrm{m} 3$ in occlusal view. Abbreviations: 11 - first lower incisor; $\mathrm{p} 4$ - fourth lower premolar; $\mathrm{m}_{n}$ - lower molars from first to third. Scale bars are $1 \mathrm{~mm}$ (B, D, F under the same scale; A and C - same scale; and G-I — same scale). The technical information and list of the 3D models of the $S$. angustirostris holotype see in 3D data set ZIN-PT-3D-01(1-6) by link: http://zin.ru/labs/theriology/eng/research/ZIN-PT-3D-01/index.html 
Appendix 1. The list of specimens of Shargainosorex angustirostris Zazhigin et Voyta, 2018 with valid catalogue's numbers of the fossil shrew collection of the Geological Institute Russian Academy of Sciences (GIN, Russia, Moscow) with additional information on locality, temporal range and presence of the digital image stacks of the specimens.

\section{Type specimens $(n=23)$ and selected specimens with the digital image stacks}

Type locality and horizon: Sharga 2, about $20 \mathrm{~km}$ SW from Sharga Village, northern slope of the IkheBaerkhe-Tologoi Rock (N46¹1', E 9503'), Shargain Gobi Desert, Mongolia, Lower part of Oshin Suite, middle Miocene (MN7-8). Material was collected by Vladimir S. Zazhigin during the summer of 1978, and
Vladimir S. Zazhigin and Evgenii V. Devjatkin during the summer of 1979. GIN collection.

Stratigraphic and geographic range: Known from the Mongolian type locality. Middle Miocene of Central Asia, MN7-8, 12.5-11.2 Ma.

\begin{tabular}{|c|c|c|}
\hline $\begin{array}{c}\text { GIN catalogue's } \\
\text { numbers }\end{array}$ & Specimen information & $\begin{array}{l}\text { Technical information } \\
\text { for } \mu \text { CT-scanning* }\end{array}$ \\
\hline GIN 959/1010 & holotype; left dentary fragment, with whole $\mathrm{i} 1, \mathrm{p} 4-\mathrm{m} 3$ & $89 / 3.98 / 0.30 / 1100$ \\
\hline GIN 959/1002 & paratype; right dentary fragment, with i1 and $\mathrm{m} 1$ & $89 / 3.98 / 0.30 / 1100$ \\
\hline GIN 959/1005 & right dentary fragment with $\mathrm{p} 4-\mathrm{m} 2$ & $89 / 3.98 / 0.30 / 1100$ \\
\hline GIN 959/1006 & right dentary fragment with $\mathrm{p} 4, \mathrm{~m} 1$ & $89 / 3.98 / 0.30 / 1100$ \\
\hline GIN 959/1007 & paratype; fragment of right hemimandible, with $\mathrm{p} 4-\mathrm{m} 3$ & $89 / 3.98 / 0.30 / 1100$ \\
\hline GIN 959/1008 & fragment of right hemimandible, with moderately worn $\mathrm{p} 4-\mathrm{m} 2$ & $89 / 3.98 / 0.30 / 1100$ \\
\hline GIN 959/1009 & paratype; right dentary fragment, with $\mathrm{p} 4-\mathrm{m} 3$ & $89 / 3.98 / 0.30 / 1100$ \\
\hline GIN 959/1012 & fragment of left hemimandible, with $\mathrm{m} 1, \mathrm{~m} 2$ & $89 / 3.98 / 0.30 / 1100$ \\
\hline GIN 959/1039 & fragment of right hemimandible, with $\mathrm{m}$ (talonid) & $89 / 3.98 / 0.30 / 1100$ \\
\hline GIN 959/1045 & paratype; fragment of left maxilla, with $\mathrm{P} 4$ & $89 / 3.98 / 0.30 / 1100$ \\
\hline GIN 959/1048 & paratype; fragment of right maxilla, with $\mathrm{P} 4$ and $\mathrm{M} 1$ & $\mathrm{n} / \mathrm{a}$ \\
\hline GIN 959/1049 & paratype; fragment of left maxilla, with $\mathrm{P} 4$ & $89 / 3.98 / 0.30 / 1100$ \\
\hline GIN 959/1050 & paratype; fragment of left maxilla, with $\mathrm{M} 1$ and M2 & $89 / 3.98 / 0.30 / 1100$ \\
\hline GIN 959/1051 & fragment of left maxilla, with heavily worn M1, M2 & $89 / 3.98 / 0.30 / 1100$ \\
\hline GIN 959/1053 & fragment of left maxilla, with M2 & $89 / 3.98 / 0.30 / 1100$ \\
\hline GIN 959/1055 & paratype; fragment of left maxilla, with $\mathrm{P} 4-\mathrm{M} 3$ & $59 / 2.00 / 0.15 / 390$ \\
\hline GIN 959/1056 & paratype; fragment of right maxilla, with $\mathrm{P} 4$ & $89 / 3.98 / 0.30 / 1100$ \\
\hline GIN 959/1059 & fragment of right maxilla, with $\mathrm{P} 4$ & $89 / 3.98 / 0.30 / 1100$ \\
\hline GIN 959/1061 & paratype; fragment of right maxilla, with $\mathrm{P} 4-\mathrm{M} 3$ & $89 / 3.98 / 0.30 / 1100$ \\
\hline GIN 959/1062 & fragment of right maxilla, with M1, M2 & $89 / 3.98 / 0.30 / 1100$ \\
\hline GIN 959/1063 & fragment of left maxilla, with M1, M2 & $89 / 3.98 / 0.30 / 1100$ \\
\hline GIN 959/1065 & paratype; fragment of left maxilla, with M2 & $89 / 3.98 / 0.30 / 1100$ \\
\hline GIN 959/1068 & paratype; right I1 (isolated) & $89 / 3.98 / 0.30 / 1100$ \\
\hline GIN 959/1069 & paratype; fragment of right premaxilla-maxilla, with A3 & $59 / 2.00 / 0.15 / 390$ \\
\hline GIN 959/1071 & paratype; left M2 (isolated) & $89 / 3.98 / 0.30 / 1100$ \\
\hline GIN 959/1073 & paratype; right M1 (isolated) & $89 / 3.98 / 0.30 / 1100$ \\
\hline GIN 959/1078 & right M1 (isolated) & $89 / 3.98 / 0.30 / 1100$ \\
\hline GIN 959/1080 & paratype; right M1 (isolated) & $\mathrm{n} / \mathrm{a}$ \\
\hline GIN 959/1086 & left M2 (isolated) & $89 / 3.98 / 0.30 / 1100$ \\
\hline GIN 959/1093 & fragment of left hemimandible, with $\mathrm{m} 1-\mathrm{m} 2$ & $89 / 3.98 / 0.30 / 1100$ \\
\hline GIN 959/1095 & fragment of right hemimandible, with $\mathrm{p} 4-\mathrm{m} 3$ & $89 / 3.98 / 0.30 / 1100$ \\
\hline GIN 959/1096 & fragment of left hemimandible, with $\mathrm{p} 4-\mathrm{m} 3$ & $89 / 3.98 / 0.30 / 1100$ \\
\hline GIN 959/1097 & paratype; right a1 (isolated) & $89 / 3.98 / 0.30 / 1100$ \\
\hline GIN 959/1098 & paratype; left dentary fragment, with i1 (proximal part), p4-m3 & $60 / 2.97 / 0.15 / 380$ \\
\hline GIN 959/1108 & paratype; fragment of right hemimandible, with $\mathrm{m} 3$ & $89 / 3.98 / 0.30 / 1100$ \\
\hline GIN 959/1114 & paratype; fragment of left hemimandible, with $\mathrm{m} 1, \mathrm{~m} 2$ & $89 / 3.98 / 0.30 / 1100$ \\
\hline GIN 959/1116 & paratype; left $\mathrm{m} 3$ (isolated) & $89 / 3.98 / 0.30 / 1100$ \\
\hline GIN 959/1164 & paratype; right dentary fragment, with $\mathrm{m} 2$ & $89 / 3.98 / 0.30 / 1100$ \\
\hline GIN 959/1221 & fragment of left hemimandible, with $\mathrm{p} 4 \mathrm{~m} 3$ & $89 / 3.98 / 0.30 / 1100$ \\
\hline $\begin{array}{l}\text { Total: } 36 \text { specimer } \\
\text { (34 under } \mu \mathrm{CT} \text { ) }\end{array}$ & & \\
\hline
\end{tabular}

Notes: * - Technical information for $\mu \mathrm{CT}$-scanning is in the following order: acceleration voltage $(\mathrm{Kv})$; resolution $(\mu \mathrm{m})$; rotation angle (deg.); exposure (ms). Used SkyScan 1172 (Bruker). Type specimens are bolded and marked by grey filling. 


\section{Specimens without digital image stacks}

Left fragments of skull $(n=9)$ :

GIN 959/1046 - fragment of left maxilla, with damaged P4; /1047 — fragment of left maxilla, with P4; $/ \mathbf{1 0 5 7}$ - fragment of left maxilla, with partly damaged P4; /1058 - fragment of left maxilla, with P4; /1064 fragment of left maxilla, with M1; /1066 — fragment of left maxilla, with M1;/1084 — fragment of left maxilla, with M2; /1085 — fragment of left maxilla, with M1; $/ 1091$ - fragment of left maxilla, with M1.

Right fragments of skull $(n=8)$ :

GIN 959/1052 - fragment of right maxilla, with $\mathrm{M} 1 ; / 1060$ - fragment of right maxilla, with heavily worn P4; /1067 - edentulous fragment of right maxilla; /1070 - edentulous fragment of right premaxillamaxilla; /1076 - fragment of right maxilla, with M1; /1077 — fragment of right maxilla, with M1; /1081 fragment of right maxilla, with $\mathrm{M} 2 ; / \mathbf{1 0 8 2}$ - fragment of right maxilla, with damaged M2 (without prc and hypoconal flange).

Left upper isolated teeth $(n=5)$ :

GIN 959/1054 - left M1, postero-lingual root is broken off; /1087 — left M2; /1088 — left M1; /1089 moderately worn left M2; /1090 — left M1.

Right upper isolated teeth $(n=3)$ :

GIN 959/1072 — right M2; /1074 — right M2; $/ 1075$ - right $\mathrm{M} 2$.

Left dentary fragments $(n=35)$ :

GIN 959/1004 - left dentary fragment, with $\mathrm{p} 4, \mathrm{~m} 1$; $/ 1014$ - left dentary fragment, with moderately worn $\mathrm{m} 1-\mathrm{m} 3 ; / \mathbf{1 0 2 3}$ - left dentary fragment, with moderately worn $\mathrm{m} 2, \mathrm{~m} 3 ; / 1027$ - left dentary fragment, with $\mathrm{m} 1 ; / \mathbf{1 0 3 2}$ - left dentary fragment, with $\mathrm{m} 1 ; / \mathbf{1 0 3 6}$ left dentary fragment, with $\mathrm{m} 1 ; / \mathbf{1 0 3 7}$ - left dentary fragment, with $\mathrm{m} 2$ (without pcd) and $\mathrm{m} 3 ; / 1044$ - left dentary fragment, with parts of $\mathrm{m} 1$ (posterior root), $\mathrm{m} 2$ (talonid) and $\mathrm{m} 3 ; / \mathbf{1 1 0 1}$ - left dentary fragment, with $\mathrm{p} 4$, $\mathrm{m} 1$ and trigonid of $\mathrm{m} 2 ; / \mathbf{1 1 0 2}$ - left dentary fragment, with $\mathrm{p} 4-\mathrm{m} 2 ; / \mathbf{1 1 0 3}$ - left dentary fragment, with $\mathrm{p} 4-\mathrm{m} 1$; $/ 1119$ - left dentary fragment, with $\mathrm{m} 1, \mathrm{~m} 2$ (talonid); $/ 1124$ - left dentary fragment, with $\mathrm{m} 1$ (talonid), $\mathrm{m} 2$, m3 (talonid); /1129 — left dentary fragment, with $\mathrm{m} 2, \mathrm{~m} 3 ; / \mathbf{1 1 3 5}$ - left dentary fragment, with $\mathrm{m} 2, \mathrm{~m} 3$; /1136 - left dentary fragment, with m1-m3;/113 - left dentary fragment, with $\mathrm{m} 1$ (talonid), $\mathrm{m} 2, \mathrm{~m} 3 ; / 1139$ left dentary fragment, with $\mathrm{m} 1 ; / \mathbf{1 1 4 0}$ - left dentary fragment, with $\mathrm{m} 1, \mathrm{~m} 2 ; / \mathbf{1 1 4 2}$ - left dentary fragment, with $\mathrm{m} 1-\mathrm{m} 3 ; / 1144$ — left dentary fragment, with $\mathrm{m} 1$ (talonid), m2; /1146 — left dentary fragment, with m1-m3; /1147 - left dentary fragment, with m1, m2; $/ 1148$ - left dentary fragment, with $\mathrm{m} 1 ; / \mathbf{1 1 5 1}$ - left dentary fragment, with $\mathrm{m} 2, \mathrm{~m} 3 ; / 1152$ - left dentary fragment, with $\mathrm{m} 3 ; / \mathbf{1 1 5 5}$ - left dentary fragment is slightly rounded by abrasion, with $\mathrm{m} 1$ (talonid), $\mathrm{m} 2$, $\mathrm{m} 3 ; / 1160$ - left dentary fragment, with $\mathrm{m} 2 ; / \mathbf{1 1 7 0}$ left dentary fragment, with $\mathrm{m} 3 ; / \mathbf{1 1 7 1}$ - left dentary fragment, with $\mathrm{m} 2 ; / \mathbf{1 1 7 2}$ - left dentary fragment, with $\mathrm{m} 2, \mathrm{~m} 3 ; / \mathbf{1 1 7 3}$ - left dentary fragment, with $\mathrm{m} 1 ; / \mathbf{1 1 7 8}$ - left dentary fragment, with $\mathrm{m} 2 ; / \mathbf{1 2 1 3}$ edentulous left dentary fragment; /1214 — edentulous left dentary fragment.

Left hemimandible fragments $(n=35)$ :

GIN 959/1011 - fragment of left hemimandible, with $\mathrm{p} 4, \mathrm{~m} 1 ; / \mathbf{1 0 2 5}$ - fragment of left hemimandible, with $\mathrm{m} 2 ; / 1040$ - edentulous fragment of left hemimandible; /1042 - edentulous fragment of left hemimandible; /1109 - fragment of left hemimandible, with $\mathrm{m} 2, \mathrm{~m} 3$ (talonid); /1110 — fragment of left hemimandible, with $\mathrm{m} 1, \mathrm{~m} 3 ; / \mathbf{1 1 1 1}$ — fragment of left hemimandible, with $\mathrm{m} 2, \mathrm{~m} 3 ; / 1112$ - fragment of left hemimandible, with $\mathrm{m} 1, \mathrm{~m} 2 ; / \mathbf{1 1 1 5}$ - fragment of left hemimandible, with $\mathrm{m} 1, \mathrm{~m} 2$; /1117 — fragment of left hemimandible, with $\mathrm{m} 1$ (talonid), m2, m3; /1120 — fragment of left hemimandible, with $\mathrm{m} 1-\mathrm{m} 3 ; / 1123$ — fragment of left hemimandible, with $\mathrm{m} 2$ (without pcd); /1134 — fragment of left hemimandible, with $\mathrm{m} 2, \mathrm{~m} 3 ; / \mathbf{1 1 6 2}$ - fragment of left hemimandible, with $\mathrm{m} 1-\mathrm{m} 3 ; / \mathbf{1 1 7 5}$ - fragment of left hemimandible, with $\mathrm{m} 1 ; / \mathbf{1 1 7 7}$ — fragment of left hemimandible, with moderately worn $\mathrm{m} 2 ; / 1182$ fragment of left hemimandible, with damaged $\mathrm{m} 3$ (talonid); /1184-1185, 1187, 1189, 1191-1192, 1194, 1196, 1199, 1203-1206, 1208-1210, 1212, 1218 edentulous fragments of left hemimandible.

Left lower isolated teeth $(n=7)$ :

GIN 959/1028 - left m2; /1033 - left m2; /1035 left $\mathrm{m} 2 ; / \mathbf{1 1 1 3}$ - left $\mathrm{m} 3 ; / \mathbf{1 1 5 3}$ — left $\mathrm{m} 1$ (?); /1154 left $\mathrm{m} 1$ fragment; /1220 — left $\mathrm{m} 3$.

Right dentary fragments $(n=48)$ :

GIN 959/1001 — right dentary fragment, with i1; $/ 1003$ - right dentary fragment is slightly rounded by abrasion, with $\mathrm{p} 4, \mathrm{~m} 1 ; / \mathbf{1 0 1 3}$ — right dentary fragment, with $\mathrm{m} 1-\mathrm{m} 3 ; / \mathbf{1 0 1 5}$ - right dentary fragment, with $\mathrm{m} 1-\mathrm{m} 3 ; / 1016$ - right dentary fragment, with $\mathrm{m} 1, \mathrm{~m} 2$; $/ \mathbf{1 0 1 7}$ — right dentary fragment, with moderately worn $\mathrm{m} 1$ and $\mathrm{m} 2 ; / \mathbf{1 0 1 8}$ - right dentary fragment, with moderately worn $\mathrm{m} 1$ and $\mathrm{m} 2 ; / 1019$ - right dentary fragment, with $\mathrm{m} 1, \mathrm{~m} 2$ and talonid of $\mathrm{m} 3 ; / \mathbf{1 0 2 1}$ — right dentary fragment, with $\mathrm{m} 1 ; / \mathbf{1 0 2 4}$ — right dentary fragment, with $\mathrm{m} 2 ; / 1026$ - right dentary fragment, with moderately worn $\mathrm{m} 2, \mathrm{~m} 3 ; / 1029$ - right dentary fragment, with $\mathrm{m} 2$; $/ 1030$ - right dentary fragment, with $\mathrm{m} 1, \mathrm{~m} 2 ; / \mathbf{1 0 3 1}$ right dentary fragment, with $\mathrm{m} 1 ; / \mathbf{1 0 3 4}$ — right dentary fragment, with $\mathrm{m} 2 ; / \mathbf{1 0 3 8}$ - right dentary fragment, with $\mathrm{m} 3 ; / 1043$ - right dentary fragment, with talonid of $\mathrm{m} 3$; /1099 — right dentary fragment, with $\mathrm{p} 4, \mathrm{~m} 1$; $/ 1100$ - right dentary fragment, with $\mathrm{p} 4-\mathrm{m} 2$ and trigonid of $\mathrm{m} 3$; /1105 — right dentary fragment, with moderately worn i1(tip is broken off), p4, m1;/1106 — right dentary fragment, with $\mathrm{p} 4, \mathrm{~m} 1 ; / \mathbf{1 1 0 7}$ — right dentary fragment, with i1 (proximal part of crown), p4, $\mathrm{m} 1 ; / \mathbf{1 1 2 1}$ — right dentary fragment, with $\mathrm{m} 1, \mathrm{~m} 2 ; / \mathbf{1 1 2 2}$ — right edentulous dentary fragment; /1126 - right dentary fragment, with $\mathrm{m} 1, \mathrm{~m} 2 ; / 1127$ - right dentary fragment, with $\mathrm{m} 2$; /1128 - right dentary fragment, with heavily worn $\mathrm{m} 1$, $\mathrm{m} 2$ (talonid); /1130 — right dentary fragment, with $\mathrm{m} 1$; $/ \mathbf{1 1 3 1}$ — right dentary fragment, with $\mathrm{m} 2$; /1132 — right dentary fragment, with $\mathrm{m} 1, \mathrm{~m} 2 ; / 1133$ - right dentary fragment, with $\mathrm{m} 1, \mathrm{~m} 2 ; / \mathbf{1 1 3 7}$ - right dentary fragment, with $\mathrm{m} 1, \mathrm{~m} 2 ; / \mathbf{1 1 4 1}$ — right dentary fragment, with $\mathrm{m} 2$; 
/1143 — right dentary fragment, with $\mathrm{m} 1$ (damaged pcd), $\mathrm{m} 2 ; / 1149$ - right dentary fragment, with $\mathrm{m} 2 ; / \mathbf{1 1 5 0}$ right dentary fragment, with $\mathrm{m} 2 ; / \mathbf{1 1 5 6}$ — right dentary fragment, with $\mathrm{m} 1, \mathrm{~m} 2 ; / \mathbf{1 1 5 7}$ — right dentary fragment, with $\mathrm{m} 1$; /1158 - right dentary fragment, with $\mathrm{m} 1$; $/ 1161$ - right dentary fragment, with $\mathrm{m} 2, \mathrm{~m} 3$ (talonid); $/ 1163$ - right dentary fragment, with $\mathrm{m} 1$ (trigonid), $\mathrm{m} 2$ (talonid); /1165 — right dentary fragment, with $\mathrm{m} 1$, $\mathrm{m} 2 ; / \mathbf{1 1 6 7}$ - right dentary fragment, with $\mathrm{m} 1 ; / \mathbf{1 1 6 8}$ right dentary fragment, with $\mathrm{m} 3 ; / \mathbf{1 1 7 6}$ — right dentary fragment, with $\mathrm{m} 1$ (without pcd and anterior root), $\mathrm{m} 2$; /1179 — right dentary fragment, with $\mathrm{m} 1 ; / \mathbf{1 2 1 5}$ — right dentary fragment, with talonid of $\mathrm{m} 2 ; / 1216$ — right dentary fragment, with base of $i 1$.

Right hemimandible fragments $(n=24)$ :

GIN 959/1020 - fragment of right hemimandible, with $\mathrm{m} 1, \mathrm{~m} 2 ; / \mathbf{1 0 2 2}$ - fragment of right hemimandible, with $\mathrm{m} 2 ; / 1092$ - fragment of right hemimandible, with $\mathrm{m} 1-\mathrm{m} 3 ; / 1094$ - fragment of right hemimandible, with $\mathrm{m} 1 ; / 1118$ - fragment of right hemimandible, with $\mathrm{m} 2, \mathrm{~m} 3 ; / 1125$ - fragment of right hemimandible, with heavily worn $\mathrm{m} 2 ; / 1145$ — fragment of right hemimandible, with $\mathrm{m} 3 ; / 1166$ - fragment of right hemimandible, with $\mathrm{m} 2, \mathrm{~m} 3 ; / \mathbf{1 1 8 1}, \mathbf{1 1 8 3}, \mathbf{1 1 8 6}, \mathbf{1 1 8 8}$, 1190 - edentulous fragments of right hemimandible; /1193 - fragment of right hemimandible, with damaged $\mathrm{m} 3$ (without ped and anterior root); /1195, 1197, 1198, 1200-1202, 1207, 1211, 1217 — edentulous fragments of right hemimandible.

Right lower isolated teeth $(n=4)$.

GIN 959/1104 — right $\mathrm{m} 2$; /1159 — right $\mathrm{m} 2$; $/ \mathbf{1 1 7 4}$ - right $\mathrm{m} 1 ; / \mathbf{1 1 8 0}$ - right $\mathrm{m} 2$.

Other specimens $(n=2)$ :

GIN 959/1083 - edentulous dentary fragment, with two damaged alveoli; /1219 — left coronoid pr. fragment.

Appendix 2. The list of specimens of Beremediini (Zazhigin \& Voyta, 2019) with valid catalogue's numbers of the fossil shrew collection of the Geological Institute of the Russian Academy of Sciences (GIN, Russia, Moscow) with additional information on locality and temporal range.

\section{List of the 16 early Pliocene-Early Pleistocene localities (with abbreviations)}

1. Andreevka 1 locality: Omskaya Oblast', Russia.

Deposits 'Andreevka 1B' (ANR/1B): early Pliocene, MN 15, Biteke Formation (= Suite), bt; material collected by Vladimir S. Zazhigin, 1993.

Deposits 'Andreevka $1 C$ ' $(\boldsymbol{A N R} / \mathbf{1 C})$ : early Pliocene, MN 15, Livenka Formation, liv; material collected by Vladimir S. Zazhigin, 1985.

2. Andreevka 2 locality: Omskaya Oblast', Russia.

Deposits 'Andreevka 2B' (ANR/2B): early Pliocene, MN 15, Biteke Formation, bt; material collected by Vladimir S. Zykin and Vladimir S. Zazhigin, 1987.

3. Kamen'-na-Obi locality (KMN): Altayskii Kray, Russia; Early Pleistocene, end of Gelasian, Irtysh Formation, irt; material collected by Liana I. Galkina, 1976.

4. Kartashovo locality (KRT): Omskaya Oblast', Russia; age undetermined; sediments redeposited; material collected by Vladimir S. Zazhigin, 1965.

5. Kizikha locality $(\boldsymbol{K Z H})$ : Altayskii Kray, Russia; age undetermined; sediments redeposited; material collected by Vladimir S. Zazhigin, 1965.

6. Livenka locality (LVK): Omskaya Oblast', Russia; early Pliocene, MN 15, stratotype of the Livenka Formation, liv; material collected by Vladimir S. Zykin and Vladimir S. Zazhigin, 1988, 2000.

7. Razdol'e locality (RZD): Altayskii Kray, Russia; Early Pleistocene, the first half of Calabrian, formation undetermined; material collected by Vladimir S. Zazhigin, 1965

8. Sibiryachikha Cave locality (SBH): Altayskii Kray, Russia; age undetermined; sediments redeposited; material collected by Nikolay D. Ovodov, 1986-87.
9. Speranskoye locality (SPR): Omskaya Oblast', Russia; early Pliocene, MN 15, liv; material collected by Vladimir S. Zazhigin, 1992.

10. Borehole 103/19 (BH-103/19): Altayskii Kray (near Troitskoye village), Russia; age undetermined; sediments redeposited; material collected by Oleg M. Adamenko and Yurii M. Kolikhalov.

11. Beregovaya locality (BRG): Republic of Buryatia, Russia; Early Pleistocene, MN 17, Chikoy Formation, chk; material collected by Margarita A. Erbajeva, 1975.

12. Bural-Obo locality: Selenge Aimag, Mongolia.

Deposits 'Bural-Obo C' (BRB/C): Early Pleistocene, MN 17, formation undetermined; material collected by Vladimir S. Zazhigin, 1970.

13. Orkhon 1 locality: Bulgan Aimag, Mongolia.

Deposits 'Orkhon 1A' (ORH/1A): late Pliocene, MN 16, formation undetermined; material collected by Vladimir S. Zazhigin, 1979.

Deposits 'Orkhon 1B'(ORH/1B): Early Pleistocene, MN 17, chk; material collected by Vladimir S. Zazhigin, 1981.

14. Shamar locality: Selenge Aimag, Mongolia.

Deposits 'Shamar A'(SHM/A): late Pliocene, MN 16, chk; material collected by Vladimir S. Zazhigin, 1970.

15. Biteke 1 locality: Kostanaiskaya Oblast', Kazakhstan.

Deposits 'Biteke 1B'(BTK/1B): early Pliocene, MN 15, stratotype of Biteke Formation, bt; material collected by Vladimir S. Zazhigin, 1980.

Deposits 'Biteke 1C' (BTK/1C): late Pliocene, $\mathrm{MN}$ 16, Selety Formation, sel; material collected by Vladimir S. Zazhigin, 1989.

16. Lebyazhye locality: Pavlodarskaya Oblast', Kazakhstan.

Deposits 'Lebyazhye C'(LBZ/C): Early Pleistocene, MN 17, irt; material collected by Vladimir S. Zazhigin, 1987. 


\section{Specimens without digital image stacks}

Beremandia fissidens (Petényi, 1864) $(n=50)$

ANR/1B $(n=1)$ : GIN 959/1254 — a fragment of right dentary, with $\mathrm{m} 1$; ANR/2B $(n=1)$ : GIN 959/1251 - a fragment of the left dentary, with damaged i1 and whole m1. ANR/1C $(n=1)$ : GIN 959/1257 right i1; KMN $(n=2)$ : GIN 959/1263 - a fragment of the left mandibular ramus, with whole coronoid and condylar processes; /1264 - left i1; KRT $(n=1)$ : GIN 959/1253 - a fragment of right hemimandible; KZH $(n=5)$ : GIN 959/1265 — a fragment of left M1; /1266 — edentulous fragment of left dentary; /1267 edentulous fragment of left dentary; /1268 - a fragment of left mandibular ramus; /1269 - a fragment of left mandibular ramus; $\mathbf{L V K}(n=2)$ : GIN 959/1273 — right M1;/1274 - edentulous fragment of the left dentary; RZD $(n=2)$ : GIN 664/201 - holotype of Nectogalinia altaica Gureev, 1979, fragment of right hemimandible, with m1-m2; GIN 664/202 — fragment of left dentary, with m1-m2; SPR $(n=1)$ : GIN 959/1258 - left I1; BH-103/19 ( $n=3)$ : GIN 959/1270 - a fragment of the right maxilla, with $\mathrm{P} 4 ; / \mathbf{1 2 7 1}$ — right $\mathrm{M} 1 ; / \mathbf{1 2 7 2}$ - a fragment of the right maxilla, with M2; BRG $(n=3)$ : GIN 959/1245 — a fragment of right dentary, with $\mathrm{m} 1-\mathrm{m} 2 ; / \mathbf{1 2 4 6}$ - a fragment of right I1 (crown part), pigmented; /1247 — fragment of left I1 (crown part), pigmented; BRB/C $(n=1)$ : GIN 959/1241 — fragments of rostrum (left premaxilla-maxilla, with I1-M2 in situ; right premaxilla, with $\mathrm{I} 1$ in situ, alveoli of $\mathrm{A} 1-\mathrm{A} 2$; right maxilla, with $\mathrm{A} 3-\mathrm{M} 2$ in situ, alveoli of $\mathrm{A} 2$; two fragments of nasal bones), and isolated right $\mathrm{A} 1$, teeth pigmented; ORH/1A $(n=1)$ : GIN 959/1243 - a fragment of left hemimandible, with $\mathrm{m} 1-\mathrm{m} 3 ; \mathbf{S H M} / \mathbf{A}$
( $n=19)$ : GIN 959/1221 — right dentary fragment, with $11-\mathrm{m} 3 ; / 1222$ — right dentary fragment, with i1, p4-m3; /1223 — right dentary fragment, with i1-m3; $/ \mathbf{1 2 2 4}$ - left dentary fragment, with $\mathrm{m} 2-\mathrm{m} 3 ; / \mathbf{1 2 2 5}-$ right dentary fragment, with heavily damaged (corroded and/or rounded) talonid of $\mathrm{m} 1$ and trigonid of $\mathrm{m} 2$; /1226 — right il fragment; /1227 — a fragment of right premaxilla-maxilla, with A $1-\mathrm{A} 3, \mathrm{P} 4-\mathrm{M} 1 ; / 1228-\mathrm{a}$ fragment of left premaxilla, with whole I1-A3; /1229 fragment of left maxilla, with $\mathrm{P} 4-\mathrm{M} 1 ; / 1230$ - a fragment of right maxilla, with $\mathrm{P} 4 ; / \mathbf{1 2 3 1}$ — a small fragment of left maxilla, with M2;/1232 — right M2, pigmented; /1233 — a small fragment of left maxilla, with damaged M1; /1234 — a small fragment of left maxilla, with damaged M2; /1235 — right I1, pigmented; $/ \mathbf{1 2 3 6}$ - left I1, pigmented; /1238 - fissident tip of right I1, pigmented; /1239 — right I1; /1240 — left I1; BTK/1B $(n=1)$ : GIN 959/1249 — right I1; BTK/1C $(n=2)$ : GIN 959/1250 - right il fragment (distal part of crown); /1312 — right i1; LBZ/C $(n=4)$ : GIN 959/1259 — a fragment of left I1; /1260 — fragment of left I1;/1261 — left M1;/1262 — right M1.

Beremendia minor Rzebik-Kowalska, $1976(n=3)$

ANR/1C $(n=2)$ : GIN 959/1255 - a fragment of the right dentary, with $\mathrm{m} 1-\mathrm{m} 2 ; / \mathbf{1 2 5 6}$ - a fragment of the right dentary, with corroded talonid $\mathrm{m} 2$ and whole $\mathrm{m} 3 ; \mathbf{B R B} / \mathbf{C}(n=1)$ : GIN 959/1242 — right whole hemimandible, teeth pigmented.

Beremendia $\mathrm{cf}$. fissidens $(n=1)$

ORH/1B $(n=1)$ : GIN 959/1244 — right M1, without roots. 